\title{
State-of-the-Art Clinical Results of Growth Hormone Secretagogues, SARM and Antagonists
}

\author{
Dr. Idiberto Jose Zotarelli Filho, MSc, Ph.D ${ }^{1}$ \\ ${ }^{1}$ Affiliation not available
}

June 4, 2020

\begin{abstract}
Introduction: The term growth hormone secretagogues (GHS) encompasses compounds that were developed to increase growth release of growth hormone (GH). GHSs include growth hormone receptor secretagogue agonists (GHS-R), whose natural ligand is ghrelin, and growth hormone releasing hormone (GHRH) agonists, to which GHRH binds as a native ligand. In the context of selective androgen receptor modulators (SARM), the presence of a Toll-IL-1 receptor domain (TIR) predicts a role for SARMs in innate immunity. SARMs are an emerging class of therapies aimed at cachexia, sarcopenia and hypogonadism or treatment of stress urinary incontinence, osteoporosis, breast cancer and Duchenne muscular dystrophy. Objective: To present the state-of-the-art scientific evidence in humans on the use of growth hormone secretagogues, SARM and antagonists. Methods: Experimental and clinical studies were included (case reports, retrospective, prospective, randomized studies and systematic review) with qualitative and/or quantitative analysis. For further specifications, the description "Clinical Trail" for refinement was added during the research, following the rules of the systematic review-PRISMA. Of 384 articles, a total of 80 articles were evaluated in full and 58 were included and discussed in this study. Results and conclusion: Several clinical trials have been conducted and completed to assess the safety and efficacy of GHS for the diagnosis and / or treatment of GH deficiency. Over the past two decades, scientists' efforts have focused on the discovery and biological characterization of new tissue-specific SARM to promote the beneficial effects of androgens with greatly reduced undesirable side effects. In this regard, numerous studies with SARM of different structures have been reported. Despite evidenced clinical and preclinical studies, no SARM has yet received full clinical approval.
\end{abstract}

Keywords: Growth hormone secretagogues. Peptides. SARM. Antagonists. Clinical Studies.

Abstract content goes here

José Wilson Ribas ${ }^{1}$, Priscilla Carlos Ribeiro Teotonio ${ }^{1}$, Idiberto José Zotarelli Filho ${ }^{2,3}$

1 REVIV CLINIC, Advanced Center for Integrative Medicine, Brasilia DF, Brazil.

2 ZOTARELLI-FILHO Scientific Work, São José do Rio Preto/SP, Brazil.

3 FACERES - Faculty of Medicine of São José do Rio Preto/SP, Brazil.

Corresponding Author: Dr. José Wilson Ribas, Reviv Clinic, Advanced Center for Integrative Medicine, Brasilia DF, Brazil.

\section{INTRODUCTION}

The term growth hormone secretagogues (GHS) encompasses compounds that were developed to increase the growth release of growth hormone (GH). GHSs include growth hormone receptor secretagogue agonists (GHS-R), whose natural ligand is ghrelin, and growth hormone-releasing hormone (GHRH) agonists, to 
which GHRH binds as a native ligand [1]. Several GHS was developed to treat or diagnose GH deficiency, namely, growth retardation, gastrointestinal dysfunction, and changes in body composition, in parallel to extensive research to identify GHRH, GHS-R, and ghrelin [1].

Ghrelin is a polypeptide containing 28 amino acids that are mainly synthesized in the stomach. Its activity stimulates GH secretion and appetite, resulting in net body weight gain [1]. From a historical angle, growth hormone-releasing peptides (GHRPs) were found before the discovery of ghrelin and the ghrelin receptor. Subsequently, GHSs, that is, ghrelin peptide mimetics, were developed. It was only later that the GHS type 1 receptor (GHS-R1a) was discovered. Finally, ghrelin was successfully isolated as a natural GHS-R1a ligand from stomach substrates in 1999. This context triggered the development of ghrelin receptor agonists, GHRPs, and GHSs; some of which have reached tests in clinical trials [2-5].

A wide range of ghrelin receptor agonist indications has been evaluated including growth retardation, gastrointestinal dysfunction, and altered body composition; some of which have received approval from the Food and Drug Administration (FDA) [6-9]. The present study focused on the history of research and the pharmacology of ghrelin receptor agonists [10-13]. Publicly released clinical trials on GHSs will be discussed in this regard [14-18].

Also, in the context of selective androgen receptor modulators (SARM), the presence of a Toll-IL-1 receptor domain (TIR) predicts a role for SARMs in innate immunity, but SARM is very different from other TIR proteins mammalian cytosolic MyD88, Mal, TRIF and TRAM, as it is not necessary to signal downstream of Toll-Like (TLR) receptors [45]. Mammalian SARM was first described in 2006 as an inhibitor of TLR signaling. Another important role for SARM is in mediating cell death [45].

Also, a recent advance reveals that SARM is enzymes that degrade NAD + and this activity is necessary for SARM to perform axonal destruction of neurons [45]. Since SARM is the only protein in the TIR domain that exhibits this activity, this suggests that at some point in the early evolution the functions of the other TIR proteins diverged [45].

In this context, SARMs are an emerging class of therapies aimed at cachexia, sarcopenia, and hypogonadism or treatment of stress urinary incontinence, osteoporosis, breast cancer, and Duchenne muscular dystrophy [46]. Since their initial scientific reports in 1998 [46], SARMs with a variety of chemical supports and pharmacological profiles have been discovered to facilitate the selective activation of androgen receptor (RA) tissues. RA is a member of the steroid receptor family of ligand-activated transcription factors, which are crucial to the organogenesis, physiology, and pathology of many tissues and are activated by comprehensive ligands such as natural hormones, peptides, synthetic molecules or hormones from growth [46].

The ability of SARMs to promote muscle and bone growth and strength, inhibit the growth of breast cancer and shrink the prostate in animals and humans is a problem based on many parameters, such as differences in the conformation of RA, expression of the enzyme metabolizer of RA and steroids between tissue recruitment, co-activator, and co-repressor $[47,48]$.

The present work aimed to present the State-of-the-Art of scientific evidence in humans on the use of growth hormone secretagogues, SARM, and antagonists.

\section{METHODS}

Experimental and clinical studies were included (case reports, retrospective, prospective, randomized studies, and systematic review) with qualitative and/or quantitative analysis. Initially, keywords were determined by searching the DeCS tool (Descriptors in Health Sciences, BIREME base) and then verified and validated by the MeSH system (Medical Subject Headings, the US National Library of Medicine) to achieve a consistent search.

\section{MeSH Terms}

The main descriptors (MeSH Terms) used were "Growth hormone secretagogues, Peptides, SARM, Antagonists and Human Studies". For further specifications, the description "Clinical Trail" for refinement was 
added during the research, following the rules of the systematic review-PRISMA (Transparent reporting of systematic reviews and meta-analyzes-https: //www.prisma-statement.org/).

The bibliographic search was carried out through online databases: PUBMED, OVID, COCHRANE LIBRARY, SCOPUS, PERIODICOS.COM AND GOOGLE SCHOLAR. The deadline and related research were set, covering all available literature on virtual libraries.

\section{Series of Articles and Eligibility}

384 articles were found involving studies in vitro, in animals, and humans. Initially, the existing title was excluded and duplicated according to the interest of only evaluating studies in human beings. After this process, the abstracts were evaluated and a new exclusion was performed. A total of 80 articles were evaluated in full and 58 were included and discussed in this study.

\section{Flow chart}

\section{GROWTH HORMONE SECRETAGOGUE}

\section{Results of major clinical studies and current status}

The results of the main clinical trials and the current status of each GHS are summarized (Table 1 ). Several clinical trials have been conducted and completed to assess the safety and efficacy of GHS for the diagnosis and/or treatment of GH deficiency. The following are the main secretagogues found in clinical studies.

\section{Sermorelin}

Sermorelin was initially developed as a diagnostic tool for GH deficiency [23]. Sermorelin increased GH release rapidly and specifically in healthy children, but not in those with GH deficiency, compared to existing provocative tests, resulting in approval for this indication by the FDA in 1990 [24]. Subsequently, the 6-month treatment with sermorelin showed a significant increase in GH release and growth speed in children with GH deficiency [25,26], and preliminary data suggested the efficacy of treatment with sermorelin for 36 months [24]. Based on these findings, sermorelin was approved by the FDA for the treatment of idiopathic GH deficiency in children with failed growth in 1997.

Sermorelin has also been tested in other clinical indications, namely, loss of muscle mass in the elderly with GH insufficiency, lipodystrophy in HIV-infected patients, and impaired cognition in the elderly [27]. The results looked promising, but the development has not yet been completed. It was reported. Also, sermorelin was discontinued by EMD Serono in 2008, due to problems with the supply of the active ingredient.

\section{Examorelin}

Examorelin has reached Phase II clinical trials for the treatment of GH deficiency and congestive heart failure, but the results have not been released. Finally, Mediolanum Farmaceutici halted the production of the examorelin for strategic reasons in 2005 [13].

\section{Tabimorelin}

Tabimorelin did not show beneficial effects on GH release in adult patients with GHD in a Phase II study [17]. Also, tabimorelin has been reported to inhibit CYP3A4, which can lead to unexpected side effects [18]. To overcome this disadvantage, Novo Nordisk has developed some compounds derived from tabimorelin, such as NNC-26-1167, although they have not yet been evaluated in clinical trials.

\section{Pralmorelin}

Plasma GH levels after a single administration of pralmorelin were greater than $15 \mu \mathrm{g}$ / L in healthy subjects, while less than $15 \mu \mathrm{g} / \mathrm{L}$ in patients with severe GHD 20, which led to the approval of pralmorelin for the diagnosis of GHD in Japan 2004 [28]. Also, pralmorelin has been shown to stimulate growth speed after 8 months of intermittent therapy in children with GHD with intact hypothalamic-pituitary (H-P) axes [28]. Although pralmorelin has reached Phase II clinical trials for the treatment of short statues, development 
has been halted. This was probably because pralmorelin did not increase plasma GH levels sufficiently in patients with GHD.

\section{Macimorelin}

A Phase III clinical trial showed that oral macimorelin was effective for the diagnosis of adult GHD with $82 \%$ sensitivity and $92 \%$ sensitivity at an ideal cutoff point of $2.7 \mathrm{GH} / \mathrm{mL}$, comparable to the GHRH and arginine test [29]. Another phase Clinical trial III was completed in 2016, to compare its effectiveness with the insulin tolerance test (ClinicalTrial.gov Identi fi c: NCT02558829), and AEterna Zentaris announced the search for the approval of macimorelin for this indication by the FDA and by the European Medicines Agency in March 2017. A Phase II clinical study for the treatment of cancer cachexia is also underway (ClinicalTrial.gov Identi fi rer: NCT01614990).

\section{Gastrointestinal indication: Ipamorelin, Ulimorelin, relamorelin and TZP-102}

\section{Ipamorelin}

Ipamorelin was introduced in Phase II clinical trials for the treatment of intestinal pseudo-obstruction (POI), sponsored by Helsinn Therapeutics. However, in patients undergoing intestinal resection, ipamorelin does not shorten the time for the first meal intake compared to placebo [30]. The Phase II clinical trial below showed no significant difference in measurable colonic functions between ipamorelin and placebo [31]. Due to these disappointing results, its development was halted.

\section{Ulimorelin}

Based on the favorable effects of ulimorelin on gastrointestinal function in animal experiments and small clinical studies, ulimorelin has progressed to randomized clinical trials for the treatment of diabetic gastroparesis or POI. In patients with diabetic gastroparesis, ulimorelin improved gastrointestinal symptoms, such as vomiting and loss of appetite, while there were no significant differences in improving gastrointestinal function between patients with IP who took ulimorelin and those who took placebo [32]. For this reason, efficacy and the risk of unexpected hypotension, its development for gastrointestinal indications has been discontinued [33].

\section{Relamorelin}

A Phase I clinical trial showed that relamorelin, compared with placebo, greatly accelerated gastric emptying in patients with diabetic gastroparesis. Subsequently, a Phase II clinical trial demonstrated that relamorelin significantly reduced the frequency of vomiting and improved gastric emptying in patients with diabetic gastroparesis [34]. These results allowed the FDA to grant a rapid appointment for relamorelin for the treatment of diabetic gastroparesis in 2016.

The safety and efficacy of relamorelin in chronic constipation were also assessed. In the Phase II clinical trial, relamorelin significantly reduced symptoms of constipation and accelerated colonic transit in female patients with chronic constipation [35]. Also, the same study showed that relamorelin rapidly increased colonic contractions without any change in irregular fundus contractions. These promising effects of relamorelin in gastrointestinal disorders may lead to a wide range of clinical applications soon [35].

\section{TZP-102}

A phase IIa study demonstrated that TZP-102 reduced abdominal symptoms without significantly improving gastric emptying in patients with diabetic gastroparesis, compared with placebo [37]. Subsequently, phase IIb trials failed to show a significant difference in improving gastrointestinal mobility between TZP -102 and placebo. No developments regarding TZP-102 have been updated recently, because Ocera Therapeutics merged with Tranzyme Pharmaceutical, the maker of TZP-102, in 2013.

Indication of body composition: Ibutamoren, Tesamorelin, Capromoreline, Anamoreline, and Macimoreline 


\section{Ibutamoren}

In the stimulating scenario of GH production, the long-term safety of treatment with growth hormone (GH) is an area of much debate. Healthy elderly people who took the MK-677 mimetic experienced a sustained increase in the amplitude of pulsatile GH and IGF-I secretion to the levels seen in young adults [38].

GH reduces abdominal visceral fat (GVA) in GH deficient and obese adults, postmenopausal women, but not in normal elderly people. Despite the increased GH levels, MK-677 did not affect GAV, perhaps because its combined orexigenic and adipogenic effects neutralized the lipolytic effects of the GH increase. Finally, although MK-677 did not reduce GVA, it did reduce LDL levels in 12 months and the unobserved effect on GH in normal elderly people [38].

In a randomized clinical trial, ibutamoren for 12 months was well tolerated and increased GH secretion and fat-free mass, but not muscle strength in healthy elderly people. However, development was halted because ibutamoren was associated with the risk of heart failure in a randomized study to examine safety and efficacy in patients with hip fractures [38].

\section{Tesamorelin}

Several randomized clinical trials have shown the beneficial effects of tesamorelin on impaired body composition in patients with HIV-associated lipodystrophy [39-42]. A meta-analysis including four clinical studies also revealed that tesamorelin decreased visceral fat and increased lean body mass. As a result, the FDA approved tesamorelin (Egriftaß) as the first-line treatment for reducing excess abdominal fat in HIV-infected patients with lipodystrophy.

\section{Capromorelin}

A Phase II clinical trial investigated the effects of capromorelin on body composition and functional performance in healthy elderly people. At 12 months, capromorelin significantly increased lean body mass and the ability to climb stairs compared to placebo. However, this study was terminated early because results at 12 months were not considered a continuation of this study [43]. As the aging process is not considered a pathological condition by the FDA, capromorelin must offer excellent results, as a survival benefit in this case. population or be applied to other clinical indications. Capromorelin has so far only been approved by the FDA as a short-term therapeutic option for improving appetite in anorexic dogs.

\section{Anamorelin}

Two-phase III, double-blind trials (ROMANA 1, NCT01387269, n = 484; ROMANA 2, NCT01387282, $\mathrm{n}$ $=495$ ) evaluated the efficacy and safety of anamorelin $100 \mathrm{mg}$ in patients with incalculable stage III / IV lung cancer and cachexia defined as [?]5\% weight loss in the last 6 months or a body mass index $<20 \mathrm{~kg} /$ $\mathrm{m} 2$. In both studies, anamorelin increased lean body mass compared to placebo (ROMANA 1: $1.10 \mathrm{~kg}$ for anamorelin, $-0.44 \mathrm{~kg}$ for placebo; ROMANA 2: $0.75 \mathrm{~kg}$ for anamorelin, $0.96 \mathrm{~kg}$ for placebo; $\mathrm{P}<0.0001$ for both), but did not significantly improve handgrip strength.56 Subsequently, an extension study, ROMANA3 (NCT01395914), involving 513 patients with ROMANA1 and ROMANA2 NSCLC, assessed the efficacy and safety of anamorelin for another 12 weeks. As in previous studies, anamorelin has been associated with a favorable safety profile and increased body weight, but not muscle strength [44]. Anamorelin showed similar results in a clinical trial that included patients with NSCLC-induced cachexia in Japan [Clinical trial record: JapicCTI-111415 (Japan Pharmaceutical Information Center Clinical Trials Although several clinical studies have shown that anamorelin increased muscle mass, but not muscle strength, anamorelin did not receive approval in 2017, despite promising results in clinical studies, because increasing muscle mass without a significant increase in muscle strength was not considered acceptable.

Table 1. Current status of the main GHS found. 


\begin{tabular}{|c|c|c|c|}
\hline SUBSTANCE & STATUS & DATE & $\begin{array}{l}\text { CLINICAL } \\
\text { INDICATIONS } \\
\text { AND DESCRIPTIONS }\end{array}$ \\
\hline Sermorelin & $\begin{array}{l}\text { FDA approved and } \\
\text { discontinued }\end{array}$ & July, 2008 & $\begin{array}{l}\text { IN SEPTEMBER 1997, } \\
\text { SERMORELIN WAS } \\
\text { APPROVED FOR THE } \\
\text { TREATMENT OF } \\
\text { GROWTH HORMONE } \\
\text { DEFICIENCY IN } \\
\text { CHILDREN }\end{array}$ \\
\hline Examorelin & Interrupted & & \\
\hline Tabimorelin & Interrupted & $\mathrm{AT}$ & $\begin{array}{l}\text { IT SEEMS } \\
\text { INTERRUPTED. }\end{array}$ \\
\hline Pralmorelin (i.v.) & Approved in Japan & October, 2004 & $\begin{array}{l}\text { DIAGNOSIS OF } \\
\text { GROWTH HORMONE } \\
\text { DEFICIENCY IN } \\
\text { ADULTS AND } \\
\text { CHILDREN (> } 4 \\
\text { YEARS). }\end{array}$ \\
\hline Ipamorelin & Interrupted & & \\
\hline Ulimorelin & Active & March, 2017 & $\begin{array}{l}\text { EVALUATING THE } \\
\text { EFFECT OF } \\
\text { ULIMORELIN IN } \\
\text { PATIENTS WITH } \\
\text { INTOLERANCE OF } \\
\text { ENTERAL FEEDING }\end{array}$ \\
\hline Relamorelin & $\begin{array}{l}\text { Currently evaluated by } \\
\text { the FDA }\end{array}$ & October, 2016 & $\begin{array}{l}\text { TREATMENT OF } \\
\text { DIABETIC } \\
\text { GASTROPARESIS. }\end{array}$ \\
\hline TZP-102 & Active & 2013 & $\begin{array}{l}\text { FDA GIVES TZP-102 A } \\
\text { QUICK DESIGNATION } \\
\text { FOR TREATMENT OF } \\
\text { DIABETIC } \\
\text { GASTROPARESIS IN } \\
2009 .\end{array}$ \\
\hline Tesamorelin & FDA approved & November, 2010 & $\begin{array}{l}\text { REDUCTION OF } \\
\text { EXCESS ABDOMINAL } \\
\text { FAT IN HIV INFECTED } \\
\text { PATIENTS WITH } \\
\text { LIPODYSTROPHY. }\end{array}$ \\
\hline Capromorelin (oral) & FDA approved & June, 2016 & $\begin{array}{l}\text { APPETITE } \\
\text { STIMULATION IN } \\
\text { DOGS WITH } \\
\text { DECREASED } \\
\text { APPETITE. }\end{array}$ \\
\hline Anamorelin & $\begin{array}{l}\text { Requested for approval at } \\
\text { EMA }\end{array}$ & November, 2015 & $\begin{array}{l}\text { CACHEXIA } \\
\text { ASSOCIATED WITH } \\
\text { NSCLC. }\end{array}$ \\
\hline
\end{tabular}




\begin{tabular}{llll}
\hline & & & CLINICAL \\
SUBSTANCE & STATUS & DATE & INDICATIONS \\
\hline Macimorelin & $\begin{array}{l}\text { Requested for FDA } \\
\text { approval }\end{array}$ & February, 2017 & DIAGNOSIS OF \\
& & GROWTH HORMONE \\
& & DEFICIENCY IN \\
& & ADULTS. \\
\hline
\end{tabular}

\section{SELECTIVE MODULATORS OF ANDROGENIC RECEPTORS - SARM}

\section{Scientific clinical results in the last 10 years}

In the past two decades, scientists' efforts have focused on the discovery and biological characterization of new tissue-specific SARM to promote the beneficial effects of androgens with greatly reduced undesirable side effects. In this regard, numerous studies with SARM of different structures have been reported, as shown in Table 2 .

Table 2. Different SARM structures [45-48].

- SARM with central arylpropionamide structure, such as S-1, S-4 (andarina), S-9, S-22

- SARM with central phenyl oxadiazole structure, such as RAD140

- SARM with central quinolinone structure, such as LGD-2226, LGD-2941, LGD-3303

- SARM with tetrahydroquinolinone core structure, such as S-40503, S-101479, S-49288

- SARM with indole core structure, such as RAD35010, Ly2452473

Despite evidenced clinical and preclinical studies, no SARM has yet received full clinical approval. However, the enormous anabolic properties of SARM muscles and bones give rise to potential misuse in sports, as has been recognized by the World Anti-Doping Agency (WADA), which has included SARM in the banned list released annually since 2008 (class S1.2, other anabolic agents) [45].

Due to its considerable variety of central chemical structure and the display of substantially different physical and chemical properties, the generation of SARM data related to ionization and dissociation of substances under analytical conditions commonly used in doping control laboratories is crucial for routine testing of sports drugs. Therefore, drug candidates have been subjected to electrospray ionization, high-resolution mass spectrometry, and electron ionization, to reveal structural information that supports the development of test methods and metabolism studies [46].

In this context, LGD-4033 (also known as VK5211, Ligandrol or Anabolicum) (4 - ((R)-2-((R)-2,2,2-trifluoro1-hydroxyethy1) pyrrolidine-1-y1) -2-trifluoro-methyl) benzonitrile) is a SARM with a central structure of pyrrolidinyl-benzonitrile [47]. A study in young, healthy men proved that LGD-4033 is safe, well-tolerated, has a favorable pharmacokinetic profile with a prolonged elimination half-life (24-36 hours), in addition to showing increased lean body mass. Longer randomized studies should assess its effectiveness in improving physical function and health benefits. Although its use is not officially approved and is not yet manufactured by a pharmaceutical company, many websites make LGD-4033 widely available and studies have reported its detection in black market products [47].

A study of LGD-4033 metabolism in human urine, as well as in a doping control sample from a human athlete, has been reported. The metabolites of microsomes by the human liver, as well as electrochemical conversion metabolites / microbial degradation of LGD-4033 have also been described [47].

GlaxoSmithKline (GSK) 2881078 is a selective non-steroidal SARM modulator under investigation by GSK for the treatment of reduced mobility and other functional limitations in men and women with muscle 
weakness associated with chronic and acute diseases [48]. Thus, in a human study, we report the safety, tolerability, pharmacokinetics, and pharmacodynamics of SARM GSK2881078. In part A, healthy young men $(\mathrm{n}=10)$ received a single dose of the study drug $(0 \mathrm{mg}, 0.05 \mathrm{mg}, 0.1 \mathrm{mg}, 0.2 \mathrm{mg}$ gsk2881078 or corresponding placebo). In part $\mathrm{b}$, the cohorts of repeated doses in men $(\mathrm{n}=65)$ were $0.05 \mathrm{mg}, 0.2 \mathrm{mg}$ and $0.08 \mathrm{mg}, 0.24$ $\mathrm{mg}, 0.48 \mathrm{mg}, 0.75 \mathrm{mg}$ or placebo; in women $(\mathrm{n}=24)$ it was $0.24 \mathrm{mg}, 0.35 \mathrm{mg}$ or placebo ( 7 days for $0.5 \mathrm{mg}$, 14 days for other doses). Pharmacokinetic analysis showed dose-proportional increases in exposure and a long half-life $>100 \mathrm{~h}$. There were no significant effects on vital signs, electrocardiograms, cardiac telemetry, or standard clinical laboratory studies. A dose-response effect was observed in the reduction of high-density lipoprotein and sex hormone-binding globulin. In women with $0.35 \mathrm{mg}$, the differences from placebo were -0.518 (95\% confidence interval: -0.703, -0.334) mmol l-1 and -39.1 (-48.5, -29.7) nmol l-1, respectively. Women showed greater sensitivity to these parameters at lower doses than men. Adverse drug-related events were mild. One woman developed a rash and was removed. Two men had elevated creatine phosphokinase after physical exertion during follow-up. Therefore, these data demonstrated pharmacodynamic effects with acceptable tolerability and support an additional clinical assessment of this SARM [48].

Still, another phase 1b study aimed at exploring, over a range of doses, the pharmacokinetic relationship and more safety and tolerability data for gsk2881078 [49]. This study also evaluated the effects of cyp3a4 inhibition on the pharmacokinetics of gsk2881078. This study followed a randomized, placebo-controlled, parallel-group, repeated dose, and dose escalation model in older healthy men and postmenopausal women. Three male and three female cohorts were studied. Dosing at each dose level was twice daily for the first 3 days, followed by once daily for up to 53 days. Repeated x-ray absorptiometry and magnetic resonance imaging were performed in the cross-section of the thigh. The effect of cyp3a4 inhibition on gsk2881078 was evaluated in a separate cohort. The gsk 2881078 was generally well tolerated and no serious adverse events were reported. Compared with the placebo, there was a greater accumulation of lean mass with all dose levels of gsk2881078. Women exhibited a greater response at lower doses than men. Transient elevations of alanine aminotransferase were observed. The effect of cyp3a4 inhibition on gks2881078 is likely to have no clinical significance. Therefore, gsk2881078 produced dose-dependent increases in lean mass, with evidence of greater sensitivity in women. The compound was well tolerated [49].

Also, the assembly of inflammasomes after infection or injury leads to the release of interleukin-1 $\beta$ (IL-1 $\beta$ ) and pyroptosis. After activation of the inflammasome, the pyroptosis cells either enter a hyperactive state defined by the secretion of IL- $1 \beta$ without cell death. The removal of the toll-il-1r SARM protein from macrophages decouples the release of inflammasome-dependent cytokines and pyroptosis, in which cells exhibit increased production of IL-1 $\beta$, but reduce pyroptosis in the same way. The increase in sarm in the cells caused less release of IL- $1 \beta$ and pyroptosis. SARM suppressed IL- $1 \beta$ by directly restricting the nlrp3 inflammasome and, therefore, caspase-1 activation [50].

A steroid compound was recently detected as $(17 \alpha, 20 \mathrm{e})-17.20$ - [(1-methoxyethylidene) bis (oxy)] - 3-oxo19-norpregna-4,20- diene-21-carboxylic acid methyl ester (yk11). This compound is described as having selective properties of androgen receptor modulators and myostatin inhibitor. As yk11 is an experimental drug candidate and an unapproved substance for humans, scientific data on its metabolism is scarce. Due to its steroid backbone and the undisputably labile derived orthoester portion, positioned in the d ring, substantial in vivometabolic conversion was anticipated [51].

Also, RA has attracted attention in the treatment of breast cancer. Due to the undesirable side effects of ar agonists, attempts have been made to develop selective RA modulators. Thus, one of these compounds is cl-4as-1. three different breast cancer cell lines were used, namely, mcf- 7 luminal cells, mda-mb-453 apocrine molecular cells, and triple-negative basal cells, mda-mb-231. The high and significant agreement was found between dihydrotestosterone (DHT) and cl-4as-1 in the regulation of gene expression in mda-mb- 453 cells. however, some differences were observed, including the expression of RA, which was regulated by DHT, but not by cl-4as-1. Also, DHT and cl-4as-1 caused a similar morphological change and reorganization of the actin structure of mda-mb-453 cells into a mesenchymal phenotype. Treatment of cells with dht resulted in the induction of the proliferation of mcf-7 and mda-mb-453 cells, but no effect was observed on the growth 
of mda-mb-231 cells. On the other hand, increasing doses of cl-4as-1 resulted in a dose-dependent inhibition of the growth of the three cell lines. This inhibition was the result of the induction of apoptosis by which cl-4as-1 caused a block in the entry of cells in the s phase, followed by DNA degradation. Therefore, these results indicate that, although cl-4as-1 has characteristics of the classic RA agonist, it has different properties that may make it useful in the treatment of breast cancer [52].

Also, a report described the discovery of RAD140, a potent non-steroidal selective modulator, orally bioavailable, non-selective steroid for RA. The characterization of RAD140 in several preclinical models of anabolic androgen action is also described. RAD140 has excellent pharmacokinetics and is a potent anabolic also in non-human primates. The general preclinical profile of RAD140 completed preclinical toxicology in rats and monkeys. At the moment, RAD140 is being prepared for phase 1 clinical studies in patients suffering from weight loss due to cancer cachexia [53].

In this sense, loss of muscle mass in cancer is a common and often hidden condition that can occur before obvious signs of weight loss and before a clinical diagnosis of cachexia can be made. Muscle wastage in cancer is an important and independent predictor of progressive functional impairment, decreased quality of life and increased mortality. Although several therapeutic agents are currently under development to treat muscle wasting or cachexia in cancer, most of these agents do not directly inhibit muscle wasting. Thus, SARMs have the potential to increase lean body mass and, therefore, muscle mass, without the undesirable side effects seen with traditional anabolic agents [54].

Thus, Enobosarm, a non-steroid SARM, is an agent in the clinical development for preventing and treating muscle wasting in cancer patients (phase 1 and 2 trials). Also, a phase 3, randomized, double-blind, placebocontrolled, multicenter, multinational trial was designed to evaluate the effectiveness of Enobosarm in preventing and treating muscle wasting in individuals who initiate first-line chemotherapy for non-chemotherapy. little. In each study, subjects will receive either placebo $(\mathrm{n}=150)$ or Enobosarm $3 \mathrm{mg}(\mathrm{n}=150)$ orally once daily for 147 days. Physical function, assessed as the power to climb stairs, and lean mass assessed by dual-energy x-ray absorptiometry, are the end points of effectiveness in both tests evaluated on the day. Based on extensive comments from the Food and Drug Administration (FDA), an individual should experience a $10 \%$ improvement in physical function compared to the baseline. To meet the definition of response in lean mass, a subject must have demonstrated no loss of lean mass compared to the baseline. Secondary end points include the durability of the assessed response. The efficacy parameters are the result of this feedback and discussion of the threshold for clinical benefit in patients at risk of muscle loss. The full results of these studies will be published shortly [54].

Also, a selective non-steroidal modulator named ly305 has been identified, which is bioavailable through a transdermal route of administration while being highly eliminated by hepatic metabolism to limit the exposure of parent compounds in the liver. The selection of this compound and its transdermal formulation was based on the optimization of skin absorption properties using in vitro and in vivo skin models. This molecule is an agonist of the perineal muscle and is a weak partial agonist of androgenic tissues, such as the prostate. When ly305 was tested on animal models of skeletal atrophy, it restored skeletal muscle mass through accelerated repair. In a model of bone fracture, ly305 remained osteoprotective in the regenerating tissue and without deleterious effects. In a small cohort of healthy volunteers, the safety and tolerability of ly305 was assessed when administered transdermally. Ly305 showed a dose-dependent increase in serum exposure and was well tolerated with minimal adverse effects. Notably, there were no statistically significant changes in hematocrit or HDL after the 4-week treatment period. Collectively, ly305 represents the first of its kind to develop a non-steroidal transdermal SARM with unique properties that may find clinical utility [55].

The gtx-024 (Enobosarm) is the first selective modulator of androgen receptors of the class, being developed for several indications in oncology. Pre-clinical studies of gtx-024 supported the evaluation of several potential drug interactions in a clinical setting. A series of open phase 1 drug interaction studies was designed to interrogate possible interactions with a cyp3a4 inhibitor (itraconazole), a cyp3a4 inducer (rifampicin), a pan-ugt inhibitor (probenid), a cyp2c9 substrate (celecoxib)) and a bcrp substrate (rosuvastatin). The 
plasma pharmacokinetics of gtx-024, its main metabolite (glucuronide gtx-024) and each substrate were characterized in detail. Administration of itraconazole did not affect the pharmacokinetics of gtx-024. Likewise, the administration of gtx-024 did not significantly alter the pharmacokinetics of celecoxib or rosuvastatin. Administration of rifampicin had the greatest impact on the pharmacokinetics of gtx- 024 of any co-administered agent and reduced the maximum plasma concentration by $23 \%$ and the area under the curve by $43 \%$. Probenecid had a complex interaction with gtx-024, so plasma levels of gtx-024 and glucuronide gtx-024 were increased by coadministration of the ugt inhibitor (50 and $112 \%$, respectively). Overall, gtx-024 was well tolerated and has very little risk of generating clinically relevant drug interactions [56].

\section{ANTAGONISTS}

Loss of skeletal muscle mass and strength is a central feature of traumatic injuries and degenerative myopathies. Unfortunately, pharmacological interventions often fail to stem the long-term decline in quality of life. REV-ERB-mediated reduced gene suppression in cultured c2c12 myoblasts has been shown to stimulate myoblast differentiation. However, the mechanisms that allow REV-ERB to pleiotropically inhibit muscle differentiation are not well known. Thus, a study elucidated the role of REV-ERB in regulating muscle differentiation and regeneration in vivo. The REV-ERB $\alpha / \beta$ regulation mechanism for muscle differentiation and regeneration was analyzed. Myoblast analysis showed that REV-ERB $\alpha$ did not transcriptionally regulate muscle differentiation through cognate elements REV-ERB/ror-response, but through a possible interaction with the regulator of nf-y cell fate in ccaat motifs. Muscle differentiation is stimulated by the release of REV-ERB from CCAAT motifs in the elements promoting and enhancing various myogenic proteins. Therefore, the interruption of REV-ERB activity in the injured muscle accelerates regenerative muscle repair/differentiation through the transcriptional detoxification of myogenic programs. Thus, REV-ERB can be a potent therapeutic target for a multitude of muscle disorders [57].

In previous investigations, we have reported that activation of the $\beta / \delta$ receptor activated by the peroxisome proliferator by gw501516 inhibits proliferation and promotes apoptosis in the undifferentiated cells of c6661 nasopharyngeal carcinoma (NPC) modulating the caspase-dependent apoptotic pathway. Thus, a study explored the mechanism by which gw501516 induces apoptosis through the expression of the microwave (mirna). Among the mirnas analyzed involved in regulating the expression of the anti-apoptotic protein bcl2, mir-206 increased significantly and specifically by gw501516 in c666-1 cells, both in vitro and in xenograft samples in vivo. The induction in mir-206 expression caused by gw501516 was able to be antagonized by the antagonist gsk3787 of ppar $\beta / \delta$ and by the dorsomorphine antagonist of ampk in cells c666-1. Suppression of gw501516 in the growth and apoptosis of c666-1 cells has been found to depend on the presence of mir-206 $[58]$.

The overexpression of mir-206 resulted in suppressed proliferation and the ability to form colonies, in addition to triggering increased apoptosis in c666-1 cells in a caspase-dependent manner. the expression of cleaved caspase 3 and caspase 9 , and the ratio of bax to bcl- 2 were increased notably by mir-206. Current data has shown that mir-206 plays a critical role in the direct promotion effect of gw501516-induced apoptosis in c666-1 cells. Also, the emphasized tumor-suppressing role of mir-206 in c666-1 cells indicates that it has the potential to provide a new therapeutic approach [58].

\section{CONCLUSION}

Several clinical trials have been conducted and completed to assess the safety and efficacy of GHS for the diagnosis and/or treatment of GH deficiency. Over the past two decades, scientists' efforts have focused on the discovery and biological characterization of new tissue-specific SARM to promote the beneficial effects

of androgens with greatly reduced undesirable side effects. In this regard, numerous studies with SARM of different structures have been reported. Despite evidenced clinical and preclinical studies, no SARM has yet received full clinical approval.

\section{Conflict of interest}

The authors declare no conflict of interest. 


\section{REFERENCES}

1. Ishida J, Saitoh M, Ebner N, Springer J, D. Anker, Von Haehling. Growth hormone secretagogues: history, mechanism of action, and clinical development. JCSM Rapid Communications 2020; 3: 25-37. DOI: $10.1002 / \mathrm{rco} 2.9$.

2. Bowers C, Chang J, Momany F, Folkers K. Effect of the enkephalins and enkephalin analogs on release of pituitary hormones in vitro. Mol Endocrinol 1977;287-292.

3. Bowers C, Momany F, Reynolds G: In vitro and in vivo activity of a small synthetic pep- tide with potent GH releasing activity. In64th Annual Meeting of the Endocrine Soci- ety, San Francisco : 1982:205.

4. Bowers C. GH releasing peptides-structure and kinetics. J Paediatric Endocrinol Metabol 1993;6:21-32.

5. Howard AD, Feighner SD, Cully DF, Arena JP. A receptor in pituitary and hypothala- mus that functions in growth hormone re- lease.Science 1996;273:974.

6. Kojima M, Hosoda H, Date Y, Nakazato M, Matsuo H, Kangawa K. Ghrelin is a growth-hormonereleasing acylated pep- tide from stomach.Nature 1999;402: 656-660.

7. Prakash A, Goa KL. Sermorelin. BioDrugs

8. 1999;12:139-157.

9. Barron JL, Coy DH, Millar RP. Growth hor- mone responses to growth hormone- releasing hormine (1-29)-NH 2 and a D-Ala2 analog in normal men. Peptides 1985;6: 575-577.

10. Carpino PA. Recent developments in ghrelin receptor (GHS-R1a) agonists and antagonists. Expert Opin Ther Pat 2002; 12:1599-1618.

11. Arvat E, Di Vito L, Maccagno B, Broglio F, Boghen MF, Deghenghi R, et al. Effects of GHRP-2 and hexarelin, two synthetic GH- releasing peptides, on GH, prolactin, ACTH and cortisol levels in man. Comparison with the effects of GHRH, TRH and hCRH. Pep- tides1997;18:885-891.

12. Imbimbo B, Mant T, Edwards M, Amin D, Dalton N, Boutignon F, et al. Growth hormone-releasing activity of hexarelin in humans. Eur J Clin Pharmacol 1994;46: 421-425.

13. Rahim A, O'Neill PA, Shalet SM. Growth hor- mone status during long-term hexarelin therapy. J Clin Endocrinol Metabol 1998; 83:1644-1649.

14. Broglio F, Benso A, Gottero C, Muccioli G, Deghenghi R, Ghigo E, et al. Endocrine activities of alexamorelin (Ala-His-D-2- methyl-Trp-Ala-Trp-D-Phe-Lys-NH2), a synthetic GH secretagogue, in humans. Eur J Endocrinol 2000;143:419-425.

15. Suckling K. Discontinued drugs in 2005: car- diovascular drugs.Expert Opin Investig Drugs 2006;15:1299-1308.

16. Hansen BS, Raun K, Nielsen KK, Johansen PB, Hansen TK, Peschke B, et al. Pharmaco- logical characterisation of a new oral GH se- cretagogue, NN703. Eur J Endocrinol 1999; 141:180-189.

17. Zdravkovic M, Søgaard B, Ynddal L, Christiansen T, Agers $\varnothing$ H, Thomsen MS, et al. The pharmacokinetics, pharmacodynamics, safety and tolerability of a single dose of NN703, a novel orally active growth hormone secretagogue in healthy male volunteers. Growth Horm IGF Res 2000;10:193-198.

18. Zdravkovic M, Christiansen T, Eliot L, Agersoe H, Thomsen MS, Falch JF, et al. The pharmacokinetics, pharmacodynamics, safety and tolerability following 7 days daily oral treatment with NN703 in healthy male subjects. Growth Horm IGF Res 2001;11: 41-48.

19. Svensson J, Monson J, Vetter T, Hansen TK, Savine R, Kann P, et al. Oral administration of the growth hormone secretagogue NN703 in adult patients with growth hor- mone deficiency. Clin Endocrinol (Oxf)2003;58:572-580.

20. Furuta S, Shimada O, Doi N, Ukai K, Nakagawa T, Watanabe J, et al. General pharmacology of KP-102 (GHRP-2), a po- tent growth hormone-releasing peptide. Arzneimittelforschung 2004;54:868-880.

21. Editorial A. Pralmorelin: GHRP 2, GPA 748, growth hormone-releasing peptide 2, KP- 102 D, KP-102 LN, KP-102D, KP-102LN. Drugs in $R$ \& $D$ 2004;5:236-239.

22. Ejskjaer N, Dimcevski G, Wo J, Hellstrom PM, Gormsen L, Sarosiek I, et al. Safety and efficacy of ghrelin agonist TZP-101 in re- lieving symptoms in patients with diabetic gastroparesis: a randomized, placebo- controlled study. Neurogastroenterol Motil2010;22:1069.

23. Losa M, Schopohl J, Muller O, Von Werder K. Stimulation of growth hormone secre- tion with human 
growth hormone releas- ing factors (GRF 1-44, GRF 1-40, GRF 1- 29) in normal subjects. $J$ Mol Med 1984;62:1140-1143.

24. Prakash A, Goa KL. Sermorelin: a review of its use in the diagnosis and treatment of children with idiopathic growth hormone deficiency.BioDrugs: Clinic Immunothera- peutics, Biopharmaceut Gene Therapy 1999;12:139-157.

25. Neyzi O, Yordam N, Oca G, Bundak R, Darendeliler F, Agikğoz E, et al. Growth re- sponse to growth hormone releasing hor- mone (1-29)-NH2 compared with growth hormone. Acta Paediatr 1993;82:1621.

26. Thorner M, Rochiccioli P, Colle M, Lanes R, Grunt J, Galazka A, et al. Once daily subcuta- neous growth hormone-releasing hormone therapy accelerates growth in growth hormone-deficient children during the first year of therapy. Geref International Study Group. J Clin Endocrinol Metabol 1996; 81:1189-1196.

27. Vitiello MV, Moe KE, Merriam GR, Mazzoni G, Buchner DH, Schwartz RS. Growth hor- mone releasing hormone improves the cognition of healthy older adults. Neurobiol Aging 2006;27:318-323.

28. Mericq Vn, Cassorla F, Salazar T, Avila A, Iñiguez Gn, Bowers CY, et al. Effects of eight months treatment with graded doses of a growth hormone $(\mathrm{GH})$-releasing peptide in GH-deficient children. $J$ Clin Endocrinol Metabol 1998;83:2355-2360.

29. Garcia JM, Swerdloff R, Wang C, Kyle M, Kipnes M, Biller BM, et al. Macimorelin (AEZS-130)stimulated growth hormone $(\mathrm{GH})$ test: validation of a novel oral stimula- tion test for the diagnosis of adult GH defi- ciency. J Clin Endocrinol Metabol 2013;98: 2422-2429.

30. Beck DE, Sweeney WB, McCarter MD, Group IS. Prospective, randomized, con- trolled, proof-ofconcept study of the Ghrelin mimetic ipamorelin for the manage- ment of postoperative ileus in bowel resec- tion patients. Int $J$ Colorectal Dis 2014;29: 1527-1534.

31. Mosińska P, Zatorski H, Storr M, Fichna J. Future treatment of constipation- associated disorders: role of relamorelin and other ghrelin receptor agonists. J Neurogastroenterol Motility2017;23:171.

32. Shaw M, Pediconi C, McVey D, Mondou E, Quinn J, Chamblin B, et al. Safety and efficacy of ulimorelin administered postop- eratively to accelerate recovery of gastroin- testinal motility following partial bowel resection: results of two randomized, placebo-controlled phase 3 trials. Diseases of the Colon \& Rectum 2013;56:888-897.

33. Popescu I, Fleshner PR, Pezzullo JC, Charlton PA, Kosutic G, Senagore AJ. The ghrelin agonist TZP-101 for management of postoperative ileus after partial colectomy: a randomized, dose-ranging, placebo-controlled clinical trial. Diseases of the Colon \&5 Rectum 2010;53:126-134.

34. Lembo A, Camilleri M, McCallum R, Sastre R, Breton C, Spence S, et al. Relamorelin re- duces vomiting frequency and severity and accelerates gastric emptying in adults with diabetic gastroparesis. Gastroenterology 2016;151:87, e86-96.

35. Acosta A, Camilleri M, Kolar G, Iturrino J, Szarka LA, Boldingh A, et al. Relamorelin re- lieves constipation and accelerates colonic transit in a phase 2, placebo-controlled, randomized trial. Clin Gastroenterol Hepatol 2015, 13;2312, e2311-2319.

36. Acosta A, Camilleri M, Busciglio I, Boldingh A, Nelson AD, Burton D. Short-term effects of relamorelin on descending colon motility in chronic constipation: a randomized, con- trolled trial. Dig Dis Sci 2016;61:852-860.

37. Ejskjaer N, Wo J, Esfandyari T, Mazen Jamal M, Dimcevski G, Tarnow L, et al. A phase 2a, randomized, double-blind 28-day study of TZP-102 a ghrelin receptor agonist for diabetic gastroparesis.Neurogastroenterol Motil 2013;25:e140-e150.

38. Adunsky A, Chandler J, Heyden N, Lutkiewicz J, Scott BB, Berd Y, et al. MK-0677 (ibutamoren mesylate) for the treatment of patients recovering from hip fracture: a multicenter, randomized, placebocontrolled phase IIb study. Arch Gerontol Geriatr2011;53:183-189.

39. Falutz J, Allas S, Kotler D, Thompson M, Koutkia P, Albu J, Trottier B, Routy J-P, Cote P, Abribat T. A placebo-controlled, dose- ranging study of a growth hormone releas- ing factor in HIV-infected patients with ab- dominal fat accumulation. AIDS 2005;19: 1279-1287.

40. Falutz J, Allas S, Blot K, Potvin D, Kotler D, Somero M, et al. Metabolic effects of a growth hormone- 
releasing factor in pa- tients with HIV. $N$ Engl J Med 2007;357: 2359-2370.

41. Falutz J, Allas S, Mamputu J-C, Assaad H, Zoltowska M, Michaud SE, et al. Long-term safety and effects of tesamorelin, a growth hormone-releasing factor analogue, in HIV patients with abdominal fat accumulation. AIDS 2008;22:1719-1728.

42. Falutz J, Potvin D, Mamputu J-C, Assaad H, Zoltowska M, Michaud S-E, et al. Ef- fects of tesamorelin, a growth hormone- releasing factor, in HIV-infected patients with abdominal fat accumulation: a randomized placebo-controlled trial with a safety extension. JAIDS2010;53:311-322.

43. White HK, Petrie CD, Landschulz W, MacLean D, Taylor A, Lyles K, et al. Effects of an oral growth hormone secretagogue in older adults.J Clin Endocrinol Metabol 2009;94:1198-1206.

44. Currow D, Temel JS, Abernethy A, Milanowski J, Friend J, Fearon KC. ROMANA 3: a phase 3 safety extension study of anamorelin in advanced non-small-cell lung cancer (NSCLC) patients with cachexia. Ann Oncol 2017;28:1949-1956.

45. Carty M, Bowie AG. SARM: From immune regulator to cell executioner. Biochem Pharmacol. 2019 Mar;161:52-62. doi: 10.1016/j.bcp.2019.01.005. Epub 2019 Jan 8.

46. Fujii S, Kagechika H. Androgen receptor modulators: a review of recent patents and reports (20122018). Expert Opin Ther Pat. 2019 Jun;29(6):439-453. doi: 10.1080/13543776.2019.1618831. Epub 2019 May 19.

47. Fragkaki AG, Sakellariou P, Kiousi P, Kioukia-Fougia N, Tsivou M, Petrou M, Angelis Y. Human in vivo metabolism study of LGD-4033. Drug Test Anal. 2018 Nov;10(11-12):1635-1645. doi: 10.1002/dta.2512. Epub 2018 Nov 8.

48. Clark RV, Walker AC, Andrews S, Turnbull P, Wald JA, Magee MH. Safety, pharmacokinetics and pharmacological effects of the selective androgen receptor modulator, GSK2881078, in healthy men and postmenopausal women. Br J Clin Pharmacol. 2017 Oct;83(10):2179-2194. doi: 10.1111/bcp.13316. Epub 2017 Jun 10.

49. Neil D, Clark RV, Magee M, Billiard J, Chan A, Xue Z, Russell A. GSK2881078, a SARM, Produces Dose-Dependent Increases in Lean Mass in Healthy Older Men and Women. J Clin Endocrinol Metab. 2018 Sep 1;103(9):3215-3224. doi: 10.1210/jc.2017-02644.

50. Carty M, Kearney J, Shanahan KA, Hams E, Sugisawa R, Connolly D, Doran CG, Muñoz-Wolf N, Gürtler C, Fitzgerald KA, Lavelle EC, Fallon PG, Bowie AG. Cell Survival and Cytokine Release after Inflammasome Activation Is Regulated by the Toll-IL-1R Protein SARM. Immunity. 2019 Jun 18;50(6):1412-1424.e6. doi: 10.1016/j.immuni.2019.04.005. Epub 2019 May 7.

51. Piper T, Dib J, Putz M, Fusshöller G, Pop V, Lagojda A, Kuehne D, Geyer H, Schänzer W, Thevis $\mathrm{M}^{4}$. Studies on the in vivo metabolism of the SARM YK11: Identification and characterization of metabolites potentially useful for doping controls. Drug Test Anal. 2018 Nov;10(11-12):1646-1656. doi: 10.1002/dta.2527. Epub 2018 Nov 18.

52. Ahram M, Mustafa E, Abu Hammad S, Alhudhud M, Bawadi R, Tahtamouni L, Khatib F, Zihlif M. The cellular and molecular effects of the androgen receptor agonist, Cl-4AS-1, on breast cancer cells. Endocr Res. 2018 Aug;43(3):203-214. doi: 10.1080/07435800.2018.1455105. Epub 2018 Mar 26.

53. Miller CP, Shomali M, Lyttle CR, O'Dea LS, Herendeen H, Gallacher K, Paquin D, Compton DR, Sahoo B, Kerrigan SA, Burge MS, Nickels M, Green JL, Katzenellenbogen JA, Tchesnokov A, Hattersley G. Design, Synthesis, and Preclinical Characterization of the Selective Androgen Receptor Modulator (SARM) RAD140. ACS Med Chem Lett. 2010 Dec 2;2(2):124-9. doi: 10.1021/ml1002508. eCollection 2011 Feb 10.

54. Crawford J, Prado CM, Johnston MA, Gralla RJ, Taylor RP, Hancock ML, Dalton JT. Study Design and Rationale for the Phase 3 Clinical Development Program of Enobosarm, a Selective Androgen Receptor Modulator, for the Prevention and Treatment of Muscle Wasting in Cancer Patients (POWER Trials). Curr Oncol Rep. 2016 Jun;18(6):37. doi: 10.1007/s11912-016-0522-0.

55. Krishnan V, Patel NJ, Mackrell JG, Sweetana SA, Bullock H, Ma YL, Waterhouse TH, Yaden BC, Henck J, Zeng QQ, Gavardinas K, Jadhav P, Saeed A, Garcia-Losada P, Robins DA, Benson CT. Development of a selective androgen receptor modulator for transdermal use in hypogonadal patients. Andrology. 2018 May;6(3):455-464. doi: 10.1111/andr.12479. Epub 2018 Mar 12. 
56. Coss CC, Jones A, Dalton JT. Pharmacokinetic drug interactions of the selective androgen receptor modulator GTx-024(Enobosarm) with itraconazole, rifampin, probenecid, celecoxib and rosuvastatin. Invest New Drugs. 2016 Aug;34(4):458-67. doi: 10.1007/s10637-016-0353-8. Epub 2016 Apr 22.

57. Welch RD, Guo C, Sengupta M, Carpenter KJ, Stephens NA, Arnett SA, Meyers MJ, Sparks LM, Smith SR, Zhang J, Burris TP, Flaveny CA. Rev-Erb co-regulates muscle regeneration via tethered interaction with the NF-Y cistrome. Mol Metab. 2017 May 19;6(7):703-714. doi: 10.1016/j.molmet.2017.05.001. eCollection $2017 \mathrm{Jul}$.

58. Gu L, Shi Y, Xu W, Ji Y. PPAR $\beta / \delta$ Agonist GW501516 Inhibits Tumorigenesis and Promotes Apoptosis of the Undifferentiated Nasopharyngeal Carcinoma C666-1 Cells by Regulating miR-206. Oncol Res. 2019 Aug 8;27(8):923-933. doi: 10.3727/096504019X15518706875814. Epub 2019 Apr 8. 